\title{
Substituent effects on solvent-free epoxidation catalyzed by dioxomolybdenum(VI) complexes supported by ONO Schiff base ligands
}

Weili Wanga ${ }^{\mathrm{a} b}$, Tomas Guerrero ${ }^{\mathrm{c}}$, Saul R. Merecias ${ }^{\mathrm{c}}$, Héctor García-Ortega ${ }^{\mathrm{c}}$, Rosa Santillan ${ }^{\mathrm{d}}$, Jean-Claude Daran ${ }^{\mathrm{a}}$, Norberto Farfán ${ }^{\mathrm{c} *}$, Dominique Agustin ${ }^{\mathrm{a}, \mathrm{b} *}$, Rinaldo Poli ${ }^{\mathrm{a}, \mathrm{e} *}$

a - CNRS; LCC (Laboratoire de Chimie de Coordination); Université de Toulouse; UPS, INPT, 205, route de Narbonne, F-31077 Toulouse, France. Fax: +33-561553003. Email: rinaldo.poli@lcc-toulouse.fr.

b - Université de Toulouse; Institut Universitaire de Technologie Paul Sabatier - Département de Chimie, Av. Georges Pompidou, BP 20258, F-81104 Castres Cedex, France. Fax : +33563351910. Email: dominique.agustin@iut-tlse3.fr.

c - Facultad de Química, Depto. de Química Orgánica, Universidad Nacional Autónoma de México, 04510, México, D. F., México

d - Departamento de Química, Centro de Investigación y de Estudios Avanzados del IPN, 07000, Apdo. Postal. 14-740, México D. F. México.

e - Institut Universitaire de France 103, bd Saint-Michel, 75005 Paris, France

\begin{abstract}
Molybdenum complexes of type $\left[\mathrm{MoO}_{2} \mathrm{~L}\right]_{\mathrm{n}}(\mathrm{L}=$ tridentate ONO Schiff base ligands based on the salicylidene-2-aminophenolato structure) have been synthesized and used as catalysts for the solvent-free epoxidation of olefins. The effect of donor (diethylamino) and/or acceptor (nitro) substituents has been studied.
\end{abstract}




\section{Graphical abstract}

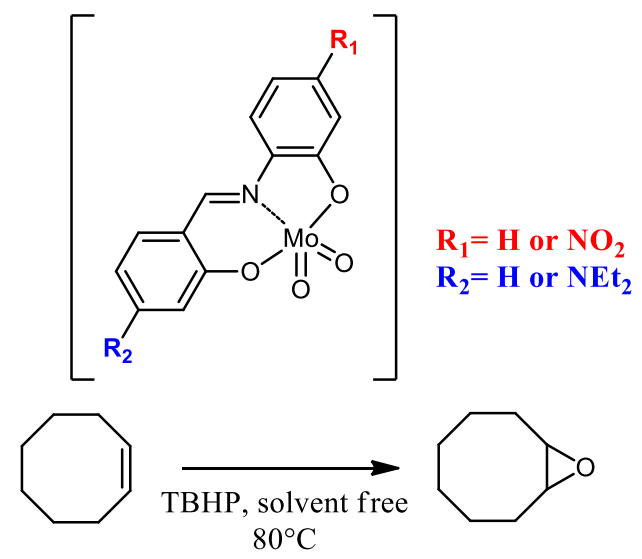

\section{Highlights}

- Synthesis and characterization of substituted tridentate Schiff-base dioxomolybdenum complexes

- These $\left[\mathrm{MoO}_{2} \mathrm{~L}\right]_{2}$ complexes are active epoxidation catalysts

- Analysis of the molecular structures

- Electronic effect of donor and acceptor substituents on the catalytic activity

\section{Keywords}

molybdenum / tridentate Schiff-base ligands / epoxidation / organic solvent-free / catalysis 


\section{Introduction}

Epoxides are among the most interesting and versatile intermediates in organic chemistry [1]. Traditionally, they are obtained from olefins using strong oxidants such as $m$ CPBA, $\mathrm{PhIO}$, and $\mathrm{NaOCl}$ in organic solvents (often chlorinated ones) [2]. These procedures are time consuming, produce waste and do not comply with the principles of green chemistry [3]. Metal catalysis with use of milder oxidants $\left(\mathrm{H}_{2} \mathrm{O}_{2}\right.$, TBHP or $\left.\mathrm{O}_{2}\right)$ is a way to promote environmentally friendlier processes [4]. Molybdenum has been shown to be one of the most active metals for olefin epoxidation catalysis and is currently used in industrial processes. The use of milder oxidant generates less toxic or useful by-products and less waste [5] but the majority of the industrial processes that have been implemented so far need the use of an organic solvent [6]. Diminishing or avoiding the use of organic solvents is one of the challenges of green chemistry to be taken into account. We are currently studying the solventfree epoxidation of olefins using coordination complexes of molybdenum [7], vanadium [8] and polyoxometalates [9]. Within these investigations, we have shown that the molybdenum complexes with the salicylidenaminophenolato (SAP) Schiff base ligand are stable and active under solvent-free conditions. Theoretical calculations on the catalytic cycle have shown that these complexes promote $\mathrm{O}$ atom transfer from TBHP to the olefin in a way reminiscent of Bartlett's mechanism [10] for the stoichiometric epoxidation by peracids. Since it is known that modification of the ligand backbone through simple functionalization affects the electrochemical properties of the molybdenum complexes [11], we wondered whether the addition of electron donor and/or withdrawing substituents in the SAP ligand would affect the catalytic performance of this molybdenum system. Thus, dimethylamino (donor) and/or nitro (withdrawing) groups have been introduced in the SAP backbone and the resulting complexes have been tested and compared in epoxidation catalysis.

\section{Experimental part}

2.1. General. All preparations were carried out in air. Water was deionised twice before use. Organic solvents (ethanol, methanol, diethylether from ACROS) were used as received: 2-amino-phenol, salicylaldehyde, 2-amino-5-nitrophenol, 4-( $N, N$-diethylamino)salicylaldehyde, cis-cyclooctene (98\% Aldrich), cyclooctene oxide (Aldrich) and TBHP (70\% in 
water, ACROS) were commercially available and used as received. Complex $\left[\mathrm{MoO}_{2}(\mathrm{acac})_{2}\right]$ was freshly synthesized as previously described [12]. The Schiff base ligands $\mathrm{H}_{2} \mathrm{~L}^{1-4}$ were prepared according to the literature procedures $[13,14,15,16]$. The physical and spectroscopic properties of these compounds are given in the SI. Complex $\left[\mathrm{MoO}_{2}\left(\mathrm{~L}^{1}\right)\right]_{2}$ was synthesized as previously described [7c].

2.2. Characterization methods. The thermogravimetric analyses were performed on a SETARAM TGA 92-16.18 thermal analyzer. The sample was placed into an alumina crucible and heated at $0.83 \mathrm{~K} \mathrm{~s}^{-1}$ in a reconstituted air flow from $15^{\circ} \mathrm{C}$ to $700^{\circ} \mathrm{C}$. An empty crucible was used as a reference. Infrared spectra were recorded using the ATR technique with a Perkin Elmer FTIR/FIR 400 spectrometer. NMR experiments were carried out in solution using DMSO- $\mathrm{d}_{6}$ as solvent, ${ }^{1} \mathrm{H},{ }^{13} \mathrm{C}$ and $2 \mathrm{D}$ NMR experiments were recorded on a Varian Unity Inova 7.2 (300 and $400 \mathrm{MHz}$ ) and a JEOL ECA 500 (500 MHz) spectrometer. High resolution mass spectra were recorded in an Agilent G1969A mass spectrometer. Catalytic reactions were followed by gas chromatography on an Agilent 6890A chromatograph equipped with FID detector, a HP5-MS capillary column $(0.30 \mathrm{~m} \times 0.25 \mathrm{~mm} \times 0.25 \mathrm{~m})$ and automatic sampling, or on a Fisons GC 8000 chromatograph equipped with FID detector and with a SPB-5 capillary column $(30 \mathrm{~m} \times 0.32 \mathrm{~mm} \times 0.25 \mathrm{~m})$. The GC parameters were quantified with authentic samples of the reactants and products. The conversion of ciscyclooctene and the formation of cyclooctene oxide were calculated from calibration curves $\left(r^{2}=0.999\right)$ relatively to an internal standard.

2.3. General procedure for the synthesis of molybdenum complexes $\left[\mathrm{MoO}_{2} \mathrm{~L}^{2-4}\right]_{2}$. In a round bottom flask equipped with a magnetic stirrer bar, $9.1 \mathrm{mmol}$ of the selected Schiff base $\mathrm{H}_{2} \mathrm{~L}^{1-4}$ and $10 \mathrm{mmol}$ of $\left[\mathrm{MoO}_{2}(\mathrm{acac})_{2}\right]$ were suspended in $50 \mathrm{~mL}$ of ethanol. The resulting suspension was stirred at reflux temperature for two hours. After that time, two thirds of the solvent were evaporated and the solution was cooled in an ice bath. The solid obtained was filtered and washed with cold ethanol and diethyl ether. The compounds were then dried under vacuum at $50^{\circ} \mathrm{C}$ for several days. The molybdenum complexes were characterized by ${ }^{1} \mathrm{H}$ and ${ }^{13} \mathrm{C}$ NMR, IR, HRMS and TGA. The carbon atoms numbering used for the assignment of the ${ }^{13} \mathrm{C}$ NMR resonances of each complex is depicted in Scheme 1. 


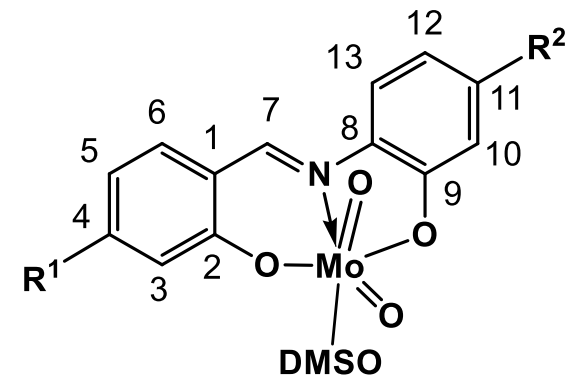

Scheme 1- Atom numbering for the assignment of the ${ }^{13} \mathrm{C}$ NMR resonances.

2.3.1. Characterization data for $\left[\mathrm{MoO}_{2}\left(L^{2}\right)\right]_{2}$. Yellow solid, $38 \%$ yield, $\mathrm{mp}>300{ }^{\circ} \mathrm{C}$. NMR ${ }^{1} \mathrm{H}\left(500 \mathrm{MHz}, \mathrm{DMSO}-d_{6}\right) \delta 9.43$ (s, 1H, H-7), 8.02 (d, 1H, $J=9.5 \mathrm{~Hz}, \mathrm{H}-13$ ), 7.82-7.79 (m, 2H, H-6, H-10), 7.62-7.58 (m, 2H, H-4, H-12), 7.09 (ddd, 1H, J = 7.5, 6.5, 1.0 Hz, H-5), $6.95(\mathrm{~d}, 1 \mathrm{H}, J=6.5 \mathrm{~Hz}, \mathrm{H}-3) .{ }^{13} \mathrm{C}\left(125 \mathrm{MHz}, \mathrm{DMSO}-d_{6}\right) \delta 162.0$ (C2), 161.5 (C7), 160.4 (C9), 148.3 (C11), 141.8 (C8), 137.5 (C4), 136.6 (C6), 122.3 (C1), 121.9 (C5), 119.6 (C3), 117.7 (C13), 115.8 (C12), 112.6 (C10). IR (ATR) v (cm $\left.{ }^{-1}\right) 1603(\mathrm{C}=\mathrm{N}), 1511\left(\mathrm{NO}_{2}\right), 1342$ $\left(\mathrm{NO}_{2}\right), 922\left(\mathrm{MoO}_{2}\right), 798$ (Mo-O-Mo). HRMS (ESI) calcd. for $\mathrm{C}_{13} \mathrm{H}_{9} \mathrm{~N}_{2} \mathrm{O}_{6} \mathrm{Mo},\left[\mathrm{M}^{+}+1\right]$ 386.9509, found 386.9511 [ $\left.\mathrm{M}^{+}+1\right]$. TGA: $37.1 \% \mathrm{MoO}_{3}$ residue (requires $37.4 \%$ ). Anal. Calc. for $\mathrm{C}_{13} \mathrm{H}_{8} \mathrm{MoN}_{2} \mathrm{O}_{6}(\mathrm{Mr}=384.15)$ : C, 40.6; H, 2.1; N, 7.3. Found: C, 40.5; H, 1.5; N, $7.1 \%$.

Characterization data for $\left[\mathrm{MoO}_{2}\left(L^{3}\right)\right]_{2}$. Brown solid, $44 \%$ yield, $\mathrm{mp}>300{ }^{\circ} \mathrm{C}$. NMR ${ }^{1} \mathrm{H}(500$ MHz, DMSO-d6) $\delta 8.89$ (s, 1H, H-7), 7.59 (dd, 1H, $J=8.0,1.0 \mathrm{~Hz}, \mathrm{H}-13), 7.44$ (d, 1H, $J=$ $9.0 \mathrm{~Hz}, \mathrm{H}-6$ ), 7.04 (ddd, 1H, $J=7.8,7.5,1.5 \mathrm{~Hz}, \mathrm{H}-11$ ), 6.82 (ddd, $1 \mathrm{H}, J=7.8 .7 .5,1.5 \mathrm{~Hz}$, H-12), 6.72 (dd, 1H, $J=8,1.5 \mathrm{~Hz}, \mathrm{H}-10), 6.41$ (dd, 1H, $J=9.0,2.5 \mathrm{~Hz}, \mathrm{H}-5), 6.07$ (d, 1H, $J=$ $2.5 \mathrm{~Hz}, \mathrm{H}-3), 3.39$ (q, 4H, $\left.J=7 \mathrm{~Hz}, \mathrm{NCH}_{2}\right), 1.09$ (t, 6H, $\left.J=7 \mathrm{~Hz}, \mathrm{CH}_{3}\right) .{ }^{13} \mathrm{C}(125 \mathrm{MHz}$, DMSO-d $\left.d_{6}\right) \delta 163.5$ (C2), 159.7 (C4), 154.8 (C7), 154.2 (C9), 137.6 (C8), 137.1 (C6), 128.0 (C11), 120.5 (C12), 117.0 (C10), 115.6 (C13), 111.6 (C1), 106.4 (C5), 99.5 (C3). 44.7 $\left(\mathrm{NCH}_{2}\right), 13.1\left(\mathrm{CH}_{3}\right)$. IR (ATR) $\vee\left(\mathrm{cm}^{-1}\right)$ 1615(C=N), $927\left(\mathrm{MoO}_{2}\right), 844(\mathrm{Mo}-\mathrm{O}-\mathrm{Mo})$. HRMS (ESI), calcd. for $\mathrm{C}_{17} \mathrm{H}_{19} \mathrm{~N}_{2} \mathrm{O}_{4} \mathrm{Mo}\left[\mathrm{M}^{+}+1\right]$ 413.0393, found 413.0400 [ $\left.\mathrm{M}^{+}+1\right]$. TGA: $35.6 \%$ $\mathrm{MoO}_{3}$ residue (requires $35.1 \%$ ). Anal. Calc. for $\mathrm{C}_{17} \mathrm{H}_{18} \mathrm{MoN}_{2} \mathrm{O}_{4}(\mathrm{Mr}=410.28)$ : C, 49.8; $\mathrm{H}$, 4.4; N, 6.8. Found: C, 49.6; H, 3.8; N, 6.7\%.

2.3.2. Characterization data for $\left[\mathrm{MoO}_{2}\left(L^{4}\right)\right]_{2}$. Brown solid, $42 \%$ yield, $\mathrm{mp}>300{ }^{\circ} \mathrm{C}$. NMR ${ }^{1} \mathrm{H}\left(500 \mathrm{MHz}, \mathrm{DMSO}-d_{6}\right) \delta 9.01$ (s, 1H, H-7), 7.75 (d, 1H, J = 9 Hz, H-13), 7.74 (dd, $1 \mathrm{H}, J=8.9,2.3 \mathrm{~Hz}, \mathrm{H}-12), 7.49$ (d, 1H, $J=5.5 \mathrm{~Hz}, \mathrm{H}-6), 7.48$ (d, 1H, $J=2.3 \mathrm{~Hz}, \mathrm{H}-10), 6.50$ $(\mathrm{dd}, 1 \mathrm{H}, J=9.0,2.5 \mathrm{~Hz}, \mathrm{H}-5), 6.12(\mathrm{~d}, 1 \mathrm{H}, J=2.5 \mathrm{~Hz}, \mathrm{H}-3), 3.44$ (q, 4H, $J=7 \mathrm{~Hz}, \mathrm{NCH}_{2}$ ), 
$1.11\left(\mathrm{t}, 6 \mathrm{H}, J=7 \mathrm{~Hz}, \mathrm{CH}_{3}\right) .{ }^{13} \mathrm{C}\left(125 \mathrm{MHz}, \mathrm{DMSO}-d_{6}\right) \delta 164.1$ (C2), 159.3 (C9), 157.4 (C7), 155.5 (C4), 146.0 (C11), 144.3 (C8), 138.3 (C6), 116.1 (C12), 115.5 (C13), 111.9 (C1), 111.5 (C10), 107.5 (C5), 99.4 (C3), $44.9\left(\mathrm{NCH}_{2}\right), 13.2\left(\mathrm{CH}_{3}\right)$. IR (ATR) v (cm $\left.{ }^{-1}\right) 1614(\mathrm{C}=\mathrm{N}), 1503$ $\left(\mathrm{NO}_{2}\right), 1325\left(\mathrm{NO}_{2}\right), 934\left(\mathrm{MoO}_{2}\right), 809$ (Mo-O-Mo). HRMS (ESI) calcd. for $\mathrm{C}_{17} \mathrm{H}_{18} \mathrm{~N}_{3} \mathrm{O}_{6} \mathrm{Mo}$, $\left[\mathrm{M}^{+}+1\right]$ 458.0244, found $458.0250\left[\mathrm{M}^{+}+1\right]$. TGA: $30.8 \% \mathrm{MoO}_{3}$ residue (requires $31.6 \%$ ). Anal. Calc. for $\mathrm{C}_{17} \mathrm{H}_{17} \mathrm{MoN}_{3} \mathrm{O}_{6}(\mathrm{Mr}=455.27)$ : C, 44.8; H, 3.8; N, 9.2. Found: $\mathrm{C}, 44.7 ; \mathrm{H}, 3.2$; $\mathrm{N}, 9.1 \%$.

2.4. Catalysis experiments. In a typical experiment, cyclooctene (1 equiv) and the catalyst ( 0.0025 equiv) were mixed and stirred in air in a round bottom flask. Acetophenone was added as internal standard (ca. $2 \%$ vs. substrate). After the reaction temperature was regulated at $80^{\circ} \mathrm{C}$, wet THBP (70\% in water, 2 equiv) was added to the mixture, starting the reaction. All complexes are only slightly soluble at room temperature but appear to completely dissolve after addition of TBHP at the reaction temperature. The color indicates that both complexes are confined in the organic phase, whereas the water phase is colorless or only slightly colored. Samples of the organic phase were periodically withdrawn. The reaction was quenched by addition of $\mathrm{MnO}_{2}$, followed by the addition of diethylether and removal of the manganese oxide and residual water by filtration through silica before GC analysis.

2.5. DFT Calculations. The geometries of all species were optimized without any symmetry constraint with the Gaussian 09 program suite [17]. The input geometries were adapted from the X-ray structures of $\left[\mathrm{MoO}_{2}(\mathrm{SAP})(\mathrm{EtOH})\right]$ [18], replacing one hydrogen by $\mathrm{NEt}_{2}$ and/or $\mathrm{NO}_{2}$ fragment depending on the molecule studied. The standard B3LYP threeparameter functional was used in conjunction with the $6-31 \mathrm{G}^{* *}$ basis set for $\mathrm{C}, \mathrm{H}, \mathrm{N}$ and $\mathrm{O}$ atoms and with the CEP-31G* basis set for molybdenum. The transition states were optimized using a preliminary scan of a relevant internal coordinate, followed by full optimization of the TS guided by knowledge of such coordinate. All optimized geometries were confirmed to be local minima (for stable molecules or reaction intermediates) or first order saddle points (for the TS's) by frequency analyses. For the TS's, analysis of the imaginary frequency confirmed the expected motion along the reaction coordinate. The calculated frequencies were also used to derive the thermochemical parameters at $298 \mathrm{~K}$ according to the standard ideal gas approximation.

2.6. X-Ray Crystallographic Study. Single crystals of $\left[\mathbf{M o O}_{2}\left(\mathbf{L}^{\mathbf{1}}\right)(\mathbf{D M S O})\right]$ and $\left[\mathrm{MoO}_{2}\left(\mathbf{L}^{3}\right)(\mathbf{D M S O})\right]$ suitable for X-ray structural analyses were mounted on an Enraf Nonius 
Kappa-CCD and the data recorded at ambient temperature whereas the compound $\left[\mathrm{MoO}_{2}\left(\mathbf{L}^{4}\right)(\mathbf{D M S O})\right]$ was mounted under inert perfluoropolyether on the tip of a loop and cooled in the cryostream of an Enraf Nonius fitted with a Bruker ApexII CCD detector. The three structures were solved by direct methods using SHELXS97 [19] or SIR97 [20] and refined by least-squares procedures on $\mathrm{F}^{2}$ using SHELXL-2013 [21]. All H atoms attached to the $\mathrm{C}$, atoms were introduced at idealised positions and treated as riding on their parent atoms in the calculations. In the first two compounds, the DMSO ligand is disordered over two positions, moreover in $\left[\mathbf{M o O}_{2}\left(\mathbf{L}^{1}\right)(\mathbf{D M S O})\right]$, the $\mathrm{L}^{1}$ ligand is disordered by pseudo symmetry around a pseudo mirror which is also involved in the disorder of the DMSO. All disordered parts were treated with the tools available in SHELXL-2013. The drawing of the molecules was realised with the help of ORTEP3.[22] Crystal data and refinement parameters are shown in Table 1. Crystallographic data (excluding structure factors) have been deposited with the Cambridge Crystallographic Data Centre as supplementary publication no. CCDC 10250221025024. Copies of the data can be obtained free of charge on application to the Director, CCDC, 12 Union Road, Cambridge CB2 1EZ, UK (fax: (+44) 1223-336-033; e-mail: deposit@ccdc.cam.ac.uk).

Table 1. Crystal data and structure refinement for the complexes $\left[\mathrm{MoO}_{2}\left(\mathrm{~L}^{1}\right)(\mathrm{DMSO})\right]$, $\left[\mathrm{MoO}_{2}\left(\mathrm{~L}^{3}\right)(\mathrm{DMSO})\right]$ and $\left[\mathrm{MoO}_{2}\left(\mathrm{~L}^{4}\right)(\mathrm{DMSO})\right]$.

\begin{tabular}{|c|c|c|c|}
\hline Empirical formula & $\begin{array}{l}{\left[\mathrm{MoO}_{2}\left(\mathrm{~L}^{1}\right)(\mathrm{DMSO})\right](\mathrm{DMSO})} \\
\mathrm{C}_{17} \mathrm{H}_{21} \mathrm{MoNO}_{6} \mathrm{~S}_{2}\end{array}$ & $\begin{array}{l}{\left[\mathrm{MoO}_{2}\left(\mathrm{~L}^{3}\right)(\mathrm{DMSO})\right]} \\
\mathrm{C}_{19} \mathrm{H}_{24} \mathrm{MoN}_{2} \mathrm{O}_{5} \mathrm{~S}\end{array}$ & $\begin{array}{l}{\left[\mathrm{MoO}_{2}\left(\mathrm{~L}^{4}\right)(\mathrm{DMSO})\right]\left(\mathrm{H}_{2} \mathrm{O}\right)_{0.5}} \\
\mathrm{C}_{19} \mathrm{H}_{24} \mathrm{MoN}_{3} \mathrm{O}_{7.5} \mathrm{~S}\end{array}$ \\
\hline Formula weight & 495.41 & 488.40 & 542.41 \\
\hline Temperature & $293(2)$ & 293(2) & 293(2) \\
\hline Wavelength & 0.71073 & 0.71073 & 0.71073 \\
\hline Crystal system & monoclinic & monoclinic & triclinic \\
\hline Space group & $P 2{ }_{1} / c$ & $P 2_{1}$ & $P-1$ \\
\hline \multicolumn{4}{|l|}{ Unit cell parameters } \\
\hline$a(\AA)$ & $12.5387(5)$ & 9.210 & $7.7016(11)$ \\
\hline$b(\AA)$ & $6.8015(2)$ & 7.947 & $12.3088(16)$ \\
\hline$c(\AA)$ & $24.0157(10)$ & 14.503 & $12.8230(19)$ \\
\hline$\alpha(\mathrm{deg})$ & 90 & 90 & $117.249(5)$ \\
\hline$\beta(\mathrm{deg})$ & $93.460(2)$ & 102.46 & $91.073(6)$ \\
\hline$\gamma(\mathrm{deg})$ & 90 & 90 & $92.406(6)$ \\
\hline Volume $\left(\AA^{3}\right)$ & $2044.37(13)$ & 1036.5 & $1078.7(3)$ \\
\hline$Z$ & 4 & 2 & 2 \\
\hline$\rho_{\text {calcd }}\left(\mathrm{g} \mathrm{cm}^{-3}\right)$ & 1.610 & 1.565 & 1.670 \\
\hline$\mu\left(\mathrm{mm}^{-1}\right)$ & 0.878 & 0.766 & 0.754 \\
\hline $\mathrm{F}(000)$ & 1008 & 500 & 554 \\
\hline Crystal size $\left(\mathrm{mm}^{3}\right)$ & $0.25 \times 0.1 \times 0.05$ & $0.25 \times 0.125 \times 0.05$ & $0.45 \times 0.025 \times 0.013$ \\
\hline $\begin{array}{l}\theta \text { range for data } \\
\text { collection }\left({ }^{\circ}\right)\end{array}$ & $2.91-27.48$ & $2.91-27.48$ & $2.65-26.43$ \\
\hline Reflections collected & 12136 & 10413 & 29410 \\
\hline $\begin{array}{l}\text { Reflections } \\
\text { independent }\end{array}$ & $4053[R($ int $)=0.0498]$ & $3770[R($ int $)=0.0275]$ & $4574[R($ int $)=0.0736]$ \\
\hline Completeness to $\theta_{\max }$ & 96.7 & 99.3 & 97.0 \\
\hline
\end{tabular}


$(\%)$

\begin{tabular}{|c|c|c|c|}
\hline $\begin{array}{l}\text { Absorption } \\
\text { correction }\end{array}$ & multiscan & multiscan & multiscan \\
\hline $\begin{array}{l}\text { Max./min. } \\
\text { transmission }\end{array}$ & $0.9591 / 0.8953$ & 0.9496 / 0.8971 & $0.7454 / 0.5136$ \\
\hline Refinement method & $\begin{array}{l}\text { Full-matrix least-squares on } \\
F^{2}\end{array}$ & $\begin{array}{l}\text { Full-matrix least- } \\
\text { squares on } F^{2}\end{array}$ & $\begin{array}{l}\text { Full-matrix least-squares on } \\
F^{2}\end{array}$ \\
\hline $\begin{array}{l}\text { Data / restraints / } \\
\text { parameters }\end{array}$ & 4053 / 9/ 304 & 3770 / 8 / 295 & 4574 / 2 / 299 \\
\hline $\begin{array}{l}\text { Goodness-of-fit on } \\
F^{2}\end{array}$ & 1.049 & 1.045 & 1.047 \\
\hline Final $R$ indices & $R_{1}=0.0520$ & $R_{1}=0.0267$ & $R_{1}=0.0638$ \\
\hline$[I>2 \sigma(I)]$ & $\mathrm{w} R_{2}=0.1144$ & $\mathrm{w} R_{2}=0.0622$ & $\mathrm{w} R_{2}=0.1616$ \\
\hline$R$ indices (all data) & $\begin{array}{l}R_{1}=0.0741 \\
\mathrm{w} R_{2}=0.1279\end{array}$ & $\begin{array}{l}R_{1}=0.0301 \\
\mathrm{w} R_{2}=0.0636\end{array}$ & $\begin{array}{l}R_{1}=0.0727 \\
\mathrm{w} R_{2}=0.1710\end{array}$ \\
\hline $\begin{array}{l}\text { Largest diff. peak / } \\
\text { hole }\end{array}$ & $1.022 /-0.768$ e. $\AA^{-3}$ & $0.304 /-0.415$ e. $\AA^{-3}$ & $2.860 /-2.130 \mathrm{e} . \AA^{-3}$ \\
\hline
\end{tabular}

\section{Results and Discussion}

\subsection{Synthesis of molybdenum complexes}

The molybdenum complexes $\left[\mathrm{MoO}_{2} \mathrm{~L}^{1-4}\right]_{2}$ were obtained by refluxing the corresponding Schiff bases $\mathrm{H}_{2} \mathrm{~L}^{1-4}$ in ethanol with $\left[\mathrm{MoO}_{2}(\mathrm{acac})_{2}\right]$ (Scheme 2). After two hours of reflux, evaporation of the solvent yielded red-orange coloured solids, presumably corresponding to the monomeric complexes $\left[\mathrm{MoO}_{2}(\mathrm{~L})(\mathrm{EtOH})\right]$. As previously shown for the $\left[\mathrm{MoO}_{2}\left(\mathrm{~L}^{1}\right)(\mathrm{EtOH})\right]$ complex, $[7 \mathrm{c}, 18,23]$ the slow release of the coordinated ethanol molecule leads to the dimeric complex $\left[\mathrm{MoO}_{2}\left(\mathrm{~L}^{1}\right)\right]_{2}$. For accurate stoichiometry control in the catalytic experiments and easier handling, the ethanol molecule was completely removed under reduced pressure from each product to yield dark solids corresponding to the binuclear complexes $\left[\mathrm{MoO}_{2}\left(\mathrm{~L}^{1-4}\right)\right]_{2}$. The IR and TGA analyses confirmed the absence of residual ethanol in the isolated products. Thermal analyses gave one mass loss with $\mathrm{MoO}_{3}$ as residue, as seen earlier with $\left[\mathrm{MoO}_{2}\left(\mathrm{~L}^{1}\right)\right]_{2}[7 \mathrm{c}, 18]$. The IR spectra of the dinuclear complexes (see Table 2) show a band for the $\mathrm{C}=\mathrm{N}$ vibration in the $1603-1615 \mathrm{~cm}^{-1}$ range and two major and narrow Mo-O bands, one corresponding to the $\mathrm{Mo}=\mathrm{O}$ stretching vibration (around 922-935 $\mathrm{cm}^{-1}$ ) and another one to a Mo-O-Mo vibration (around 798-844 $\mathrm{cm}^{-1}$ ) indicating the dimeric nature of these species. Indeed, for polymeric forms the latter vibration is broader and displaced to lower frequencies. Mass spectrometry showed in all cases the presence of the $\left[\mathrm{MoO}_{2} \mathrm{~L}\right]$ fragment with a $\mathrm{m} / \mathrm{z}$ value corresponding to the mass of the molecular ion +1 . The ${ }^{1} \mathrm{H}$ NMR investigations of the molybdenum complexes were performed in DMSO- $d^{6}$, yielding the expected signals for the Schiff base ligand, displaced from those of the $\mathrm{H}_{2} \mathrm{~L}$ molecule In 
particular, the imine signal was significantly downfield shifted (see Table 1). It should be noted that under these conditions the observed compounds are probably the mononuclear DMSO adducts, since these can be obtained as single crystals from the DMSO solutions (see the X-ray characterization in the next section). The imine proton shows a characteristic shift depending on the substituent present in the ligand backbone.

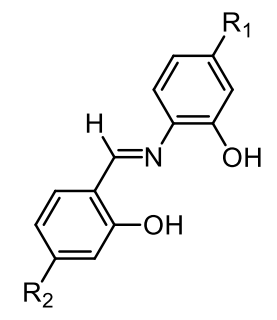

$\mathrm{R}_{1}=\mathrm{H}, \mathrm{R}_{2}=\mathrm{H}\left(\mathrm{H}_{2} \mathrm{~L}^{1}\right)$

$\mathrm{R}_{1}=\mathrm{NO}_{2}, \mathrm{R}_{2}=\mathrm{H}\left(\mathrm{H}_{2} \mathrm{~L}^{2}\right)$

$\mathrm{R}_{1}=\mathrm{H}, \mathrm{R}_{2}=\mathrm{NEt}_{2}\left(\mathrm{H}_{2} \mathrm{~L}^{3}\right)$

$\mathrm{R}_{1}=\mathrm{NO}_{2}, \mathrm{R}_{2}=\mathrm{NEt}_{2}\left(\mathrm{H}_{2} \mathrm{~L}^{4}\right)$

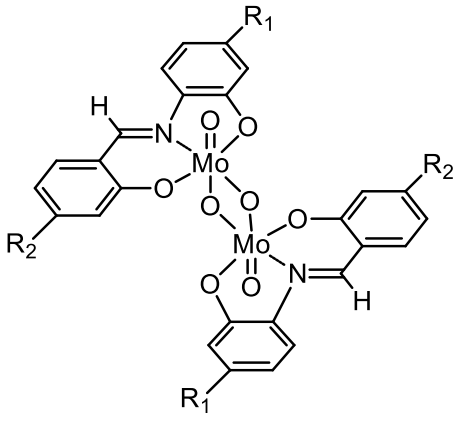

$\mathrm{R}_{1}=\mathrm{H}, \mathrm{R}_{2}=\mathrm{H}\left[\mathrm{MoO}_{2} \mathrm{~L}^{1}\right]_{2}$

$\mathrm{R}_{1}=\mathrm{NO}_{2}, \mathrm{R}_{2}=\mathrm{H}\left[\mathrm{MoO}_{2} \mathrm{~L}^{2}\right]_{2}$

$\mathrm{R}_{1}=\mathrm{H}, \mathrm{R}_{2}=\mathrm{NEt}_{2}\left[\mathrm{MoO}_{2} \mathrm{~L}^{3}\right]_{2}$

$\mathrm{R}_{1}=\mathrm{NO}_{2}, \mathrm{R}_{2}=\mathrm{NEt}_{2}\left[\mathrm{MoO}_{2} \mathrm{~L}^{4}\right]_{2}$

Scheme 2- Synthesis pathway of dimeric Mo complexes.

Table 2 - Selected IR and ${ }^{1} \mathrm{H}$ NMR data for ligands and complexes.

\begin{tabular}{|l|l|l|l|l|}
\hline Compound & \multicolumn{3}{|c|}{$\mathrm{IR}^{\mathrm{a}}$} & ${ }^{1} \mathrm{H} \mathrm{NMR}^{\mathrm{b}}$ \\
\hline & $\mathrm{C}=\mathrm{N}$ & $\mathrm{Mo}=\mathrm{O}$ & $\mathrm{Mo}-\mathrm{O}-\mathrm{Mo}$ & $\mathrm{CH}=\mathrm{N}$ \\
\hline$\left[\mathrm{MoO}_{2}\left(\mathrm{~L}^{1}\right)\right]_{2}$ & 1608 & 935 & 808 & $9.25(8.99)$ \\
\hline$\left[\mathrm{MoO}_{2}\left(\mathrm{~L}^{2}\right)\right]_{2}$ & 1603 & 922 & 798 & $9.43(8.99)$ \\
\hline$\left[\mathrm{MoO}_{2}\left(\mathrm{~L}^{3}\right)\right]_{2}$ & 1615 & 927 & 844 & $8.89(8.61)$ \\
\hline$\left[\mathrm{MoO}_{2}\left(\mathrm{~L}^{4}\right)\right]_{2}$ & 1614 & 934 & 809 & $9.01(8.77)$ \\
\hline
\end{tabular}

${ }^{a}$ Solid state. ${ }^{\mathrm{b}}$ In DMSO- $d^{6}$ solution (values for the corresponding $\mathrm{H}_{2} \mathrm{~L}$ molecule in parentheses).

\section{2. $X$-ray characterization}

Tridentate Schiff bases complexes of type $\left[\mathrm{MoO}_{2} \mathrm{~L}(\mathrm{DMSO})\right]$ are known to be easily crystallized in DMSO [24]. Single crystals of compounds [ $\left.\mathrm{MoO}_{2}\left(\mathrm{~L}^{1}\right)(\mathrm{DMSO})\right]$, $\left[\mathrm{MoO}_{2}\left(\mathrm{~L}^{3}\right)(\mathrm{DMSO})\right]$ and $\left[\mathrm{MoO}_{2}\left(\mathrm{~L}^{4}\right)(\mathrm{DMSO})\right]$ have been obtained by slow evaporation of ethanol from ethanol/DMSO solutions and analyzed X-ray diffraction. The resulting 
molecular structures are described herein. While compound $\left[\mathrm{MoO}_{2}\left(\mathrm{~L}^{1}\right)(\mathrm{DMSO})\right]$ crystallized with one additional DMSO molecule and compound $\left[\mathrm{MoO}_{2}\left(\mathrm{~L}^{4}\right)(\mathrm{DMSO})\right]$ with one water molecule per two molecules of complex, the structure of compound $\left[\mathrm{MoO}_{2}\left(\mathrm{~L}^{3}\right)(\mathrm{DMSO})\right] \mathrm{did}$ not contain any solvent of crystallization. Views of the three molecular structures are in Figures 1-3, and relevant bond distances and angles are compared in Table 3.

For all compounds, the system shows the presence of a cis- $\left\{\mathrm{MoO}_{2}\right\}^{2+}$ fragment surrounded by a tridentate ONO ligand in doubly deprotonated form $\left(\mathrm{L}^{2-}\right)$. An octahedral geometry around the molybdenum is observed, two cis-positions of the octahedron being occupied by two oxido oxygen atoms (angles in the range $104.8(2)^{\circ}-105.4(1)^{\circ}$ ), and three mer-positions being occupied by the ONO tridentate ligand. The sixth position is occupied by a molecule of DMSO with binding through its $\mathrm{O}$ atom.

In the case of $\mathrm{L}^{1}$ and $\mathrm{L}^{3}$, the DMSO ligand shows disorder. For $\left[\mathrm{MoO}_{2}\left(\mathrm{~L}^{1}\right)(\mathrm{DMSO})\right]$, the DMSO disorder may be related to a disorder of the imine function linking the two aromatic rings. The $\mathrm{Mo}(1)-\mathrm{O}(1)$ and $\mathrm{Mo}(1)-\mathrm{O}(2)$ bonds are identical and the aromatic rings of the two forms are superimposed. The two different ligand positions around the molybdenum atom, particularly the different orientations of the Mo-N bond in the two possible arrangements, possibly induce the DMSO positional disorder. The same explanation, however, cannot be valid for the $\left[\mathrm{MoO}_{2}\left(\mathrm{~L}^{3}\right)(\mathrm{DMSO})\right]$ structure, since there is no disorder in the Schiff base orientation. The diethylamino group is quasi-coplanar with the aromatic group in the structures of $\left[\mathrm{MoO}_{2}\left(\mathrm{~L}^{3}\right)(\mathrm{DMSO})\right]$ and $\left[\mathrm{MoO}_{2}\left(\mathrm{~L}^{4}\right)(\mathrm{DMSO})\right]$ (dihedral angles between the phenyl $\mathrm{C}_{6}$ ring and the $\mathrm{NC}_{2}$ fragment of $11.2(4)^{\circ}$ and $4.8(5)^{\circ}$, respectively), showing $\pi$ conjugation ( $\mathrm{sp}^{2}$ hybridization for the $\mathrm{N}$ atom), which is confirmed by the $\mathrm{N}$ atom trigonal planarity with a sum of the three bond angles of $360.0(4)^{\circ}$ and $359.8(4)^{\circ}$, respectively). Finally, the $\mathrm{NO}_{2}$ group in the structure of $\left[\mathrm{MoO}_{2}\left(\mathrm{~L}^{4}\right)(\mathrm{DMSO})\right]$ is also quasi coplanar with the aromatic ring, with a dihedral angle of 5.0(6) ${ }^{\circ}$ for O11-N11-C14-C13.

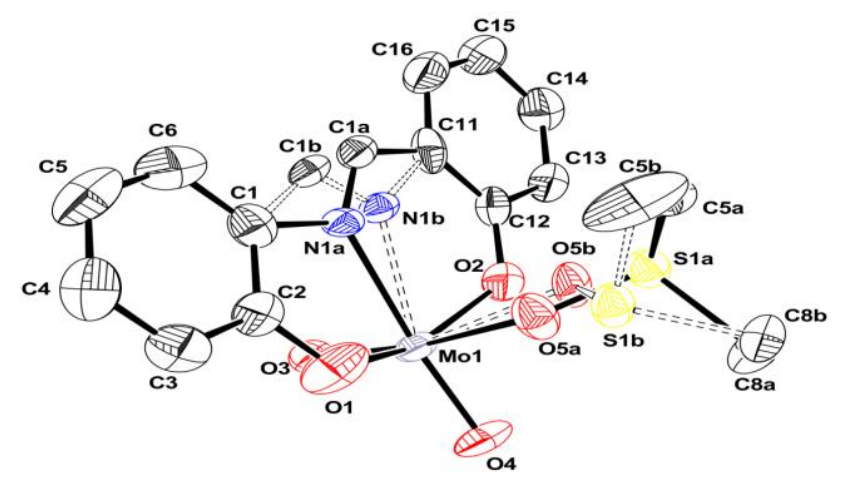


Figure 1 - ORTEP view of $\left[\mathrm{MoO}_{2}\left(\mathrm{~L}^{1}\right)(\mathrm{DMSO})\right]$. The ellipsoids are drawn at the $30 \%$ probability level. The second form is represented by dotted lines.

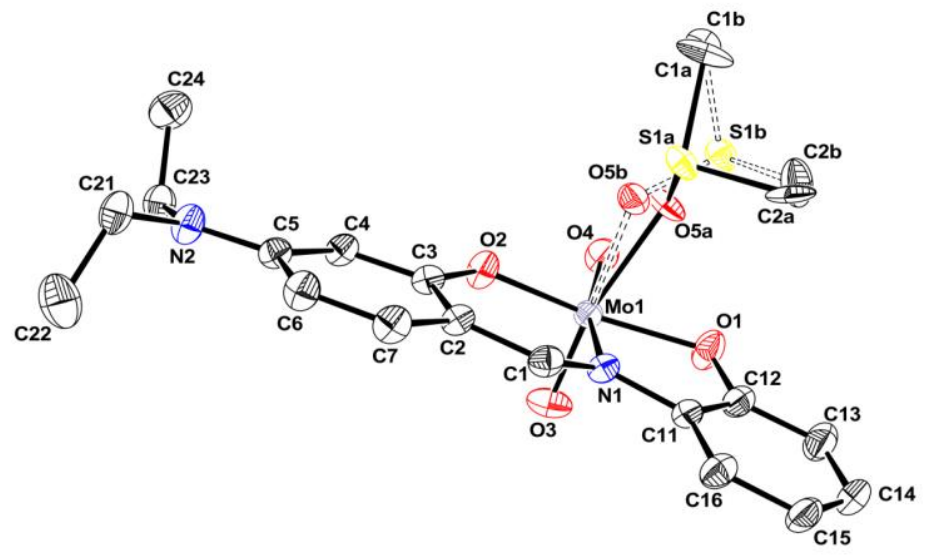

Figure 2- ORTEP view of $\left[\mathrm{MoO}_{2}\left(\mathrm{~L}^{3}\right)(\mathrm{DMSO})\right]$. The ellipsoids are drawn at the $30 \%$ probability level. The second position of DMSO is represented by dotted lines.

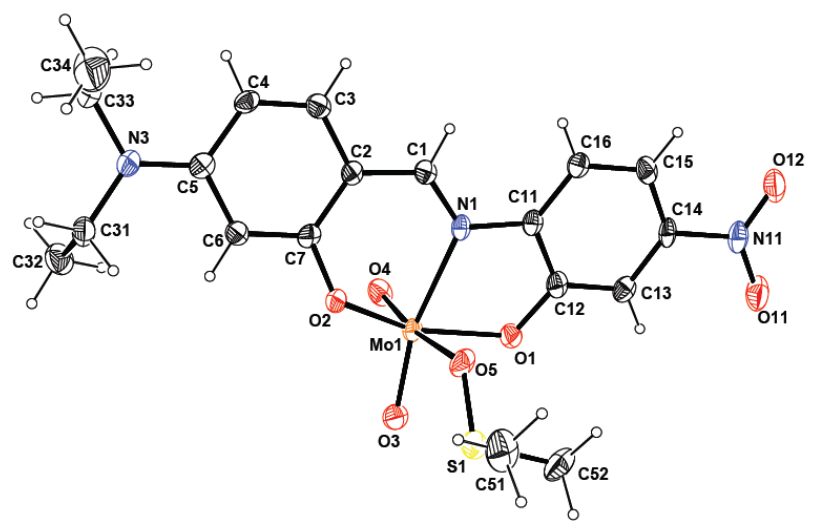

Figure 3- ORTEP view of $\left[\mathrm{MoO}_{2}\left(\mathrm{~L}^{4}\right)(\mathrm{DMSO})\right]$. The ellipsoids are drawn at the $30 \%$ probability level.

Table 3 - Selected bond lengths and angles for all compounds.

\begin{tabular}{|l|l|l|l|}
\hline & {$\left[\mathbf{M o O}_{2}\left(\mathbf{L}^{\mathbf{1}}\right)(\mathbf{D M S O})\right]$} & {$\left[\mathbf{M o O}_{2}\left(\mathbf{L}^{\mathbf{3}}\right)(\mathbf{D M S O})\right]$} & {$\left[\mathrm{MoO}_{2}\left(\mathbf{L}^{\mathbf{4}}\right)(\mathbf{D M S O})\right]$} \\
\hline Bonds & & & \\
\hline Mo=O & $1.696(4)$ & $1.687(4)$ & $1.701(3)$ \\
& $1.686(4)$ & $1.698(3)$ & $1.707(2)$ \\
\hline Mo-O & $1.929(4)$ & $1.926(3)$ & $1.941(3)$ \\
& $1.943(4)$ & $1.973(3)$ & $1.980(3)$ \\
\hline Mo- & $2.267(6)$ & $2.23(1)$ & $2.318(3)$ \\
O(DMSO) & & & \\
\hline Mo-N & $2.281(8)$ & $2.266(3)$ & $2.245(3)$ \\
\hline
\end{tabular}




\begin{tabular}{|l|l|l|l|}
\hline $\mathrm{CH}=\mathrm{N}$ & $1.27(1)$ & $1.297(5)$ & $1.308(5)$ \\
\hline Angles & & & \\
\hline $\mathrm{O}=\mathrm{Mo}=\mathrm{O}$ & $104.8(2)$ & $105.2(2)$ & $105.4(1)$ \\
\hline $\mathrm{O}-\mathrm{Mo}-\mathrm{O}$ & $151.9(2)$ & $152.7(1)$ & $152.4(1)$ \\
\hline
\end{tabular}

\subsection{Catalysis results}

Molybdenum tridentate complexes with structures very close to $\mathrm{L}^{1}$ have been tested in epoxidation by several authors in organic solvents [25]. With the aim of designing a cleaner process, we are exploring solvent-free epoxidation conditions [7-9], i.e. using aqueous TBHP as oxidant (water only being the oxidant carrier and not a solvent for the catalytic reaction) and no added organic solvent.

All complexes have been tested under the same experimental solvent-free conditions and using the same substrate (cyclooctene) already used for the previously reported epoxidation with $\left[\mathrm{MoO}_{2}\left(\mathrm{~L}^{1}\right)\right]_{2}[7 \mathrm{c}]$ in order to evaluate the potential role of the substituents in the ligand backbone on the catalytic activity. In order to ensure solubility of all complexes in the reaction medium, a very low catalyst/substrate ratio $(0.25 / 100)$ was used. While the complexes do not dissolve in the substrate phase at room temperature, they become fully soluble in the organic phase upon warming in the presence of the TBHP oxidant, which is also transferred to the organic substrate phase. The small amount of water originating from the oxidant solution remains as a separate colourless phase. The results have been compiled in Table 4 and the kinetic results are shown in Figure 4.

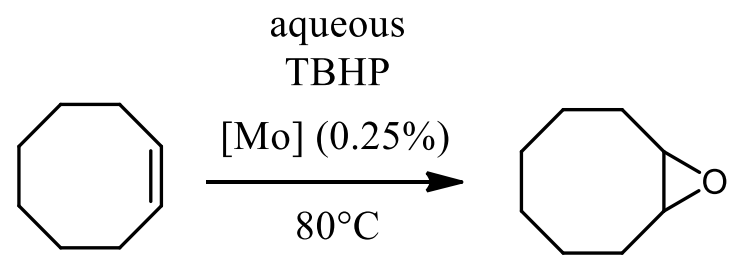

Scheme 3 - Catalyzed epoxidation reaction with $\left[\mathrm{MoO}_{2}\left(\mathrm{~L}^{1-4}\right)\right]_{2}$ complexes.

Table 4. Relevant results for the cyclooctene epoxidation catalysis. ${ }^{\mathrm{a}}$

\begin{tabular}{|c|c|c|c|c|}
\hline Complex & Conversion & Epoxide selectivity & TON & TOF $^{\mathbf{b}}\left(\mathbf{h}^{-1}\right)$ \\
\hline$\left[\mathrm{MoO}_{2}\left(\mathrm{~L}^{1}\right)\right]_{2}$ & 71 & 94 & 286 & 195 \\
{$\left[\mathrm{MoO}_{2}\left(\mathrm{~L}^{2}\right)\right]_{2}$} & 86 & 96 & 346 & 344 \\
{$\left[\mathrm{MoO}_{2}\left(\mathrm{~L}^{3}\right)\right]_{2}$} & 62 & 93 & 252 & 167 \\
{$\left[\mathrm{MoO}_{2}\left(\mathrm{~L}^{4}\right)\right]_{2}$} & 73 & 91 & 293 & 192 \\
\hline
\end{tabular}


[a] Conditions: substrate $/[\mathrm{Mo}]=400: 1 ; \mathrm{T}=80^{\circ} \mathrm{C}$; time $=4 \mathrm{~h}$. [b]calculated from initial slope (30 min).

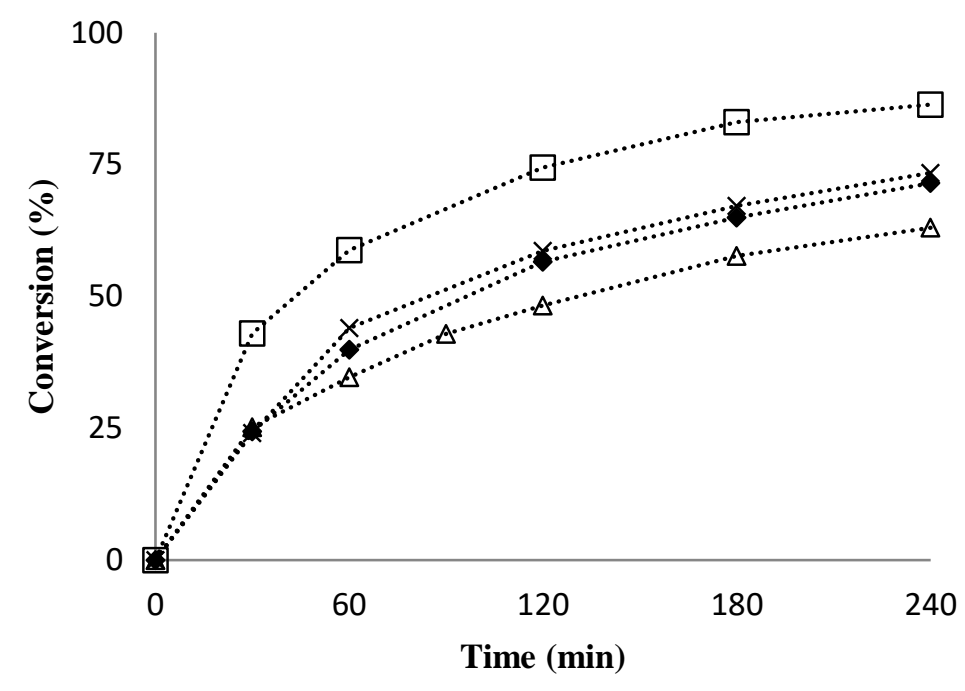

Figure 4-. Kinetic profile of converted cyclooctene vs. time with dioxidomolybdenum(VI) catalysts: $\left[\mathrm{MoO}_{2}\left(\mathrm{~L}^{1}\right)\right]_{2}(\diamond),\left[\mathrm{MoO}_{2}\left(\mathrm{~L}^{2}\right)\right]_{2}(\square),\left[\mathrm{MoO}_{2}\left(\mathrm{~L}^{3}\right)\right]_{2}(\Delta),\left[\mathrm{MoO}_{2}\left(\mathrm{~L}^{4}\right)\right]_{2}(\times)$. Conditions: substrate/[Mo] $=400: 1 ; \mathrm{T}=80{ }^{\circ} \mathrm{C}$.

The cyclooctene conversion after $4 \mathrm{~h}$ decreases in the following order $\left[\mathrm{MoO}_{2} \mathrm{~L}^{2}\right]>$ $\left[\mathrm{MoO}_{2} \mathrm{~L}^{4}\right] \approx\left[\mathrm{MoO}_{2} \mathrm{~L}^{1}\right]>\left[\mathrm{MoO}_{2} \mathrm{~L}^{3}\right]$. The selectivity, however, is always high (always greater than $90 \%$ ). The presence of the electron withdrawing $\mathrm{NO}_{2}$ group (ligand $\mathrm{L}^{2}$ ) has a small beneficial effect on the activity, while the $\mathrm{NEt}_{2}$ donor group (ligand $\mathrm{L}^{3}$ ) shows a weak detrimental effect. When both groups are present within the structure (ligand $\mathrm{L}^{4}$ ), the activity is very close to that of the parent SAP backbone (ligand $\mathrm{L}^{1}$ ). 


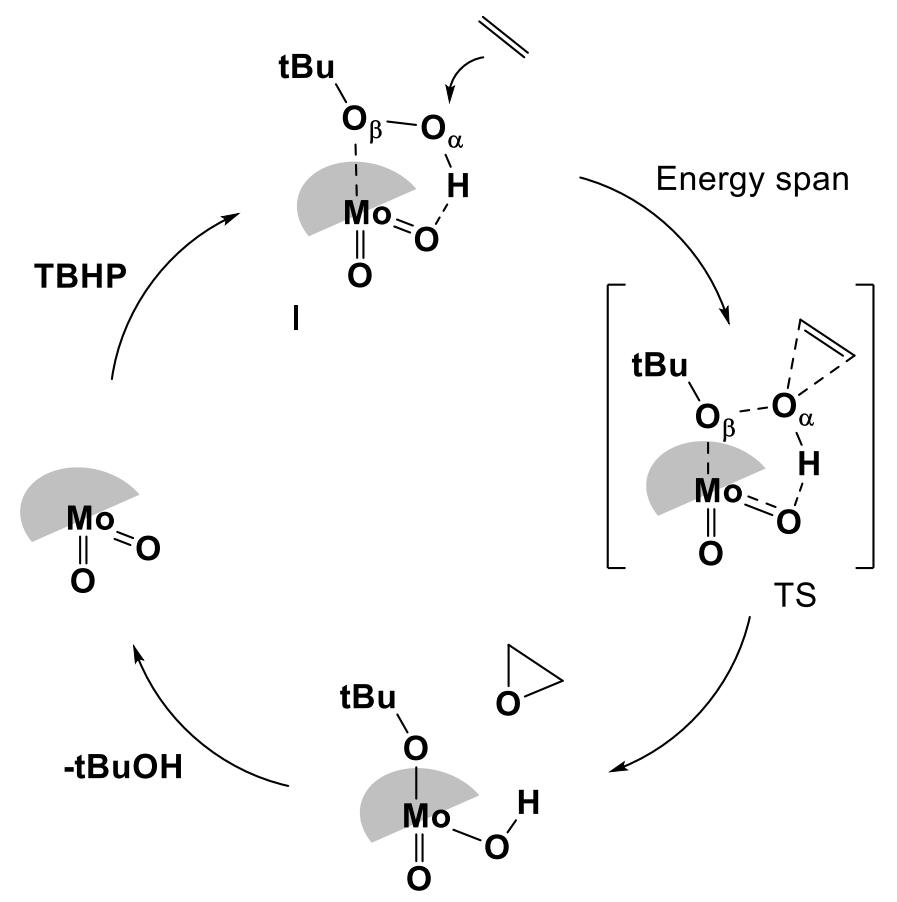

Scheme 4 - Most plausible mechanism for the epoxidation catalytic cycle with $\left[\mathrm{MoO}_{2}(\mathrm{~L})\right]$ $[7 \mathrm{c}]$.

The mechanism of the catalytic cycle for the reaction catalyzed by complex $\left[\mathrm{MoO}_{2}\left(\mathrm{~L}^{1}\right)\right]_{2}$, as suggested by experimental evidence and a DFT study, is recalled in Scheme $4[7 \mathrm{c}]$. The catalytically active species is the 5-coordinate $\left[\mathrm{MoO}_{2}\left(\mathrm{~L}^{1}\right)\right]$ monomer, which is able to activate the oxidant by coordination with assistance by $\mathrm{H}$-bonding to one oxido ligand. The $\left[\mathrm{MoO}_{2}\left(\mathrm{~L}^{1}\right)\right] \cdots$ TBHP adduct is able to transfer the $\mathrm{O}_{\alpha}$ atom to the external olefin in a way reminiscent of the Bartlett mechanism of stoichiometric olefin epoxidation by peracids [10]. The $\left[\mathrm{Mo}(\mathrm{O} t \mathrm{Bu})(\mathrm{OH})\left(\mathrm{L}^{1}\right)\right]$ intermediate generated by the $\mathrm{O}_{\alpha}$ atom transfer step then closes the cycle by eliminating $t \mathrm{BuOH}$. Under the hypothesis that the mechanism of is the same for all complexes, we can intuitively estimate that the electron-withdrawing nitro substituent on the SAP ring favours the approach of TBHP to the molybdenum atom and logically also the atom transfer. However, since the cycle energy span is given by the gap between the TBHP adduct (resting state) and the $\mathrm{O}$ atom transfer transition state, it is necessary that the $\mathrm{NO}_{2}$ stabilizes the latter more than the former in order to provide an accelerating effect. The opposite situation would occur upon introduction of the electron-donating diethylamino group. These assumptions have been supported by theoretical calculations. 


\subsection{Mechanistic rationalization through DFT calculations}

We have extended the recently published DFT investigation of the catalytic cycle for the SAP $\left(\mathrm{L}^{1}\right)$ system, using ethylene as the model olefin, to the corresponding systems containing $\mathrm{L}^{2}, \mathrm{~L}^{3}$ and $\mathrm{L}^{4}$. As mentioned above, on the basis of experimental mechanistic information gathered on the SAP $\left(\mathrm{L}^{1}\right)$ system [7c] it was concluded that the active form of the catalyst is the mononuclear 5-coordinate $\left[\mathrm{MoO}_{2}\left(\mathrm{~L}^{1}\right)\right]$ species and the most plausible (lowest energy span) pathway is recalled in Scheme 4, with an energy span of $22.5 \mathrm{kcal} / \mathrm{mol}$ on the enthalpy scale.

The results of the calculations with the four systems have been summarized in Figure 5. The coordination of TBHP to $\left[\mathrm{MoO}_{2}(\mathrm{~L})\right]$ stabilizes the system by $8.4-8.6 \mathrm{kcal} / \mathrm{mol}$ on the enthalpy scale, the electronic effect of the ligand substituents being very small. Entropic effects are rather equivalent for the various systems, yielding Gibbs energy changes that are also restrained within a small range. The greater stabilization is provided by the $\mathrm{L}^{2}$ ligand, containing the electron-withdrawing nitro group, but the electron-donating diethylamino group in $\mathrm{L}^{3}$ also provides a weak stabilizing effect. The very small extent of these changes is

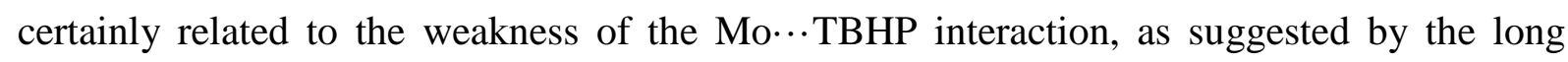
Mo $\cdots \mathrm{O}_{\beta}$ distance and to the competing electronic effects on the $\mathrm{Mo} \cdots \mathrm{O}_{\beta}$ and $\mathrm{Mo}=\mathrm{O} \cdots \mathrm{H}$ interactions in the $\left[\mathrm{MoO}_{2}\left(\mathrm{~L}^{1}\right)\right] \cdots$ TBHP adduct (I in Scheme 4). Figure 6 shows views of these resting states for the four different catalysts, with relevant distances. Indeed, the Mo $\cdots \mathrm{O}_{\beta}$ distance follows the trend $\mathrm{L}^{3}>\mathrm{L}^{4}>\mathrm{L}^{1}>\mathrm{L}^{2}$, the longer one being assosciated to the ligand with the electron-donating $\mathrm{Et}_{2} \mathrm{~N}$ group and the shorter one to the electron-withdrawing $\mathrm{NO}_{2}$ group. The presence of both groups yields an intermediate distance, close to that observed with the parent $\mathrm{L}^{1}$ ligand. Conversely, the $\mathrm{Mo}=\mathrm{O} \cdots \mathrm{H}$ becomes progressively longer along the same series: $\mathrm{L}^{3}<\mathrm{L}^{4}<\mathrm{L}^{1}<\mathrm{L}^{2}$. The O-O and O-H distances in the TBHP molecule and the $\mathrm{M}=\mathrm{O}$ distance in the pentacoordinated $\left[\mathrm{MoO}_{2}(\mathrm{~L})\right]$ species do not appear significantly altered by the electronic effects of the ligand substituent. 


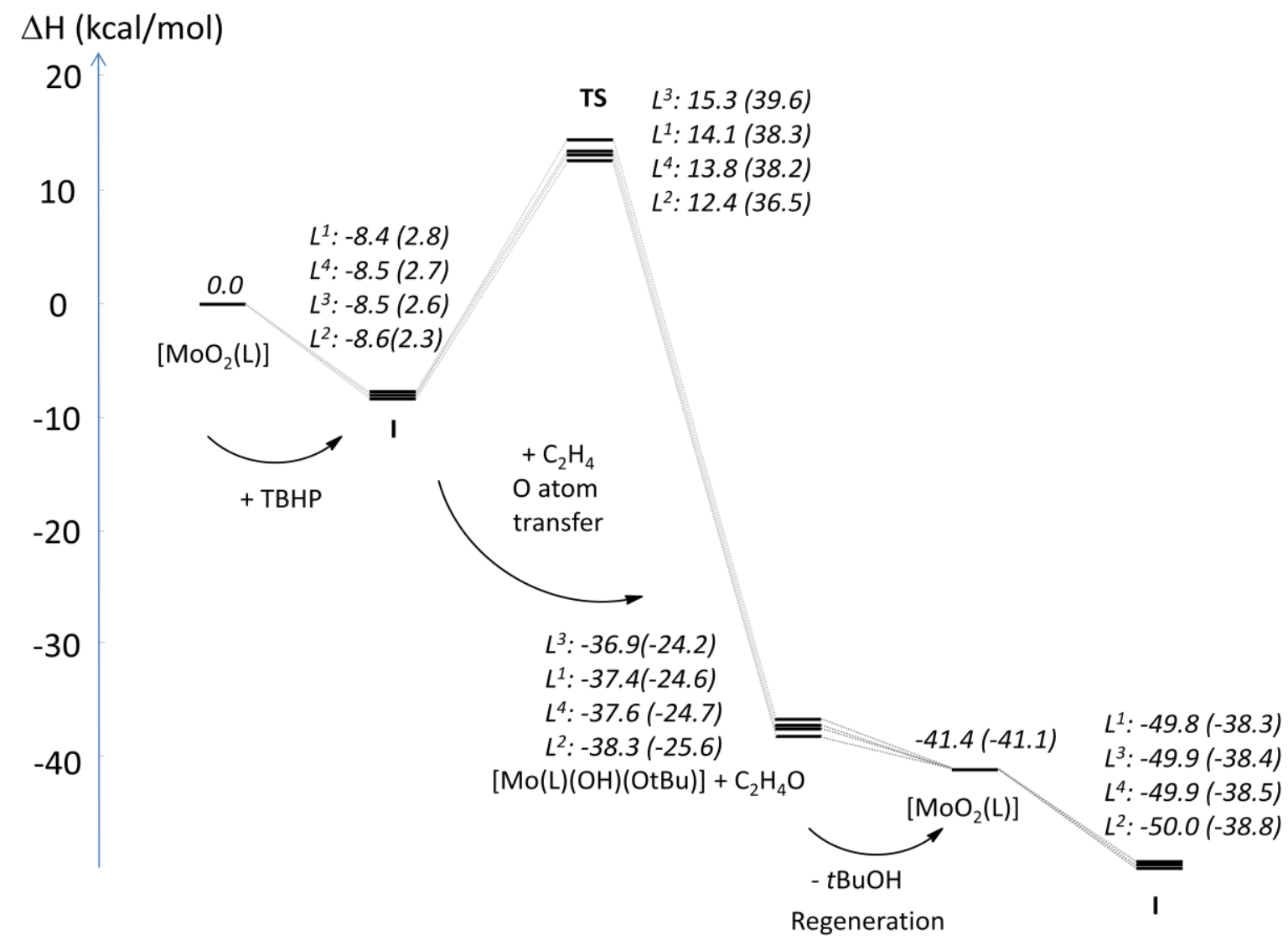

Figure 5 - Energy profile of the reaction along the three catalytic cycles of Scheme 4 . The indicated values are relative enthalpies (with Gibbs energies in parentheses) at $298 \mathrm{~K}$ in $\mathrm{kcal} / \mathrm{mol}$. 


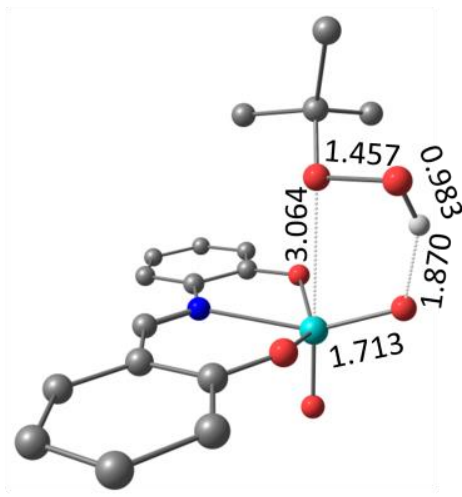

$\mathrm{L}^{1}$

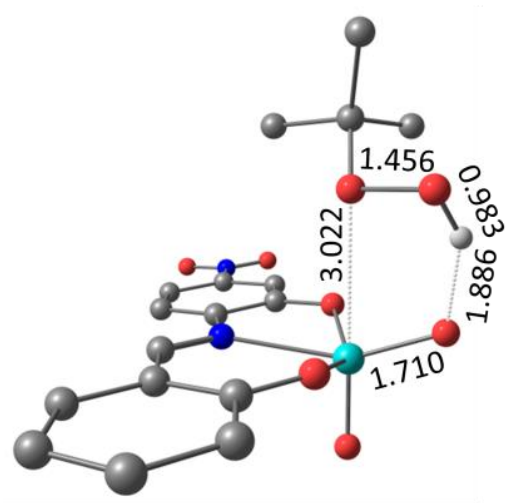

$\mathrm{L}^{2}$
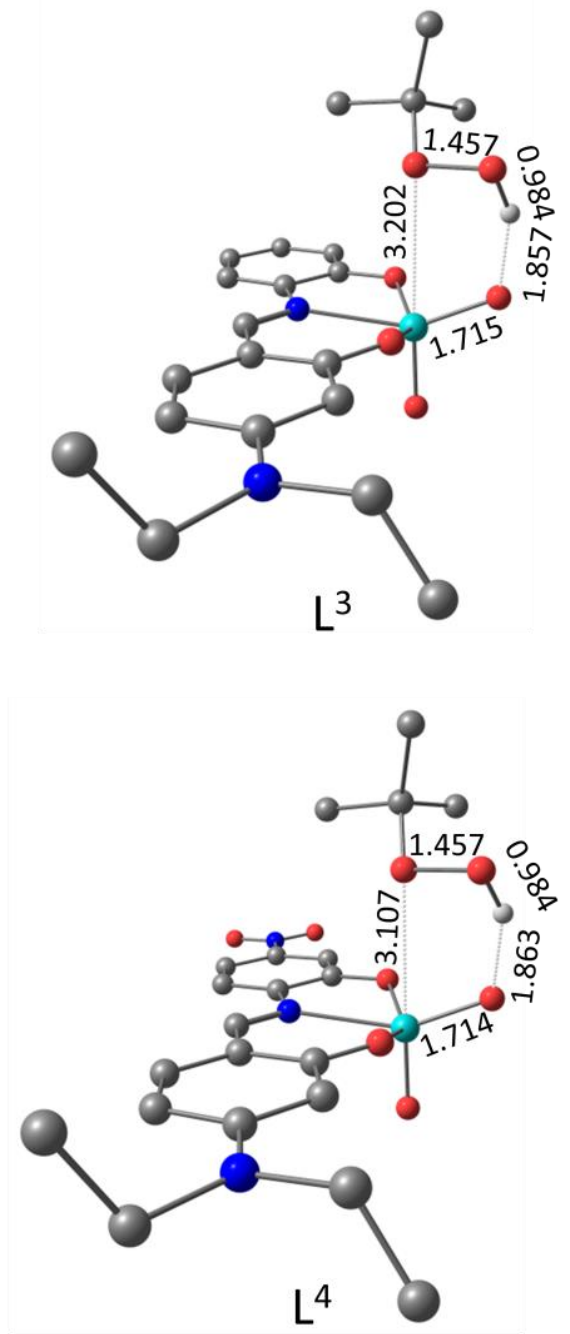

Figure 6. Views and selected distances of the optimized $\left[\mathrm{MoO}_{2}(\mathrm{~L})\right] \cdots \mathrm{TBHP}$ adducts for the four different catalysts. All $\mathrm{H}$ atoms except the $\mathrm{H}$ atom of the TBHP reagent have been removed for the sake of clarity.

On the other hand, the effect of the ligand substituents on the energy of the rate determining transition state is more substantial. Taking the pentacoordinated $\left[\mathrm{MoO}_{2}(\mathrm{~L})\right]$ complex as the reference for the energy scale, the more electron withdrawing $\mathrm{L}^{2}$ ligand stabilizes the TS by $1.7 \mathrm{kcal} / \mathrm{mol}$ relative to the parent $\mathrm{L}^{1}$ ligand, whereas the more electron donating $\mathrm{L}^{3}$ ligand destabilizes it by $0.8 \mathrm{kcal} / \mathrm{mol}$. The combination of both substituents in $\mathrm{L}^{4}$ provides a very weak stabilizing effect of $0.2 \mathrm{kcal} / \mathrm{mol}$. The structural analysis of the TS geometries (see Figure 7) rationalizes the stronger energetic effect as being essentially related to the stronger Mo $\cdots \mathrm{O}_{\beta}$ interaction. Indeed, the trend observed for the $\mathrm{Mo} \cdots \mathrm{O}_{\beta}$ distance $\left(\mathrm{L}^{3}>\right.$ $\mathrm{L}^{4}>\mathrm{L}^{1}>\mathrm{L}^{2}$ ) is the same as for intermediate $\mathbf{I}$. Although the span of the Mo $\cdots \mathrm{O}_{\beta}$ distance in 
the transition state on going from $\mathrm{L}^{3}$ to $\mathrm{L}^{2}(0.055 \AA)$ is in fact smaller than in intermediate $\mathbf{I}$ $(0.180 \AA)$, the effect on the energy span is of course greater because of the greater strength of the incipient covalent bond. The $\mathrm{Mo}=\mathrm{O} \cdots \mathrm{H}$ distances in the TS are significantly shorter than in the corresponding intermediates $\mathbf{I}$ because of the incipient proton transfer from TBHP to the oxido ligand, but the interaction remains weak and the electronic effect of the substituents in the two systems is similar (span from $\mathrm{L}^{2}$ to $\mathrm{L}^{3}$ of $0.032 \AA$ in the TS, vs. $0.029 \AA$ in intermediate I). Thus, the competing effect on the $\mathrm{O} \cdots \mathrm{H}$ interaction is less relevant than for intermediate $\mathbf{I}$. The contribution of the $\mathrm{O} \cdots \mathrm{O}$ breaking process does not seem to be affected by the $\mathrm{L}$ substituents, as judged by the relatively uniform $\mathrm{O} \cdots \mathrm{O}$ distance.

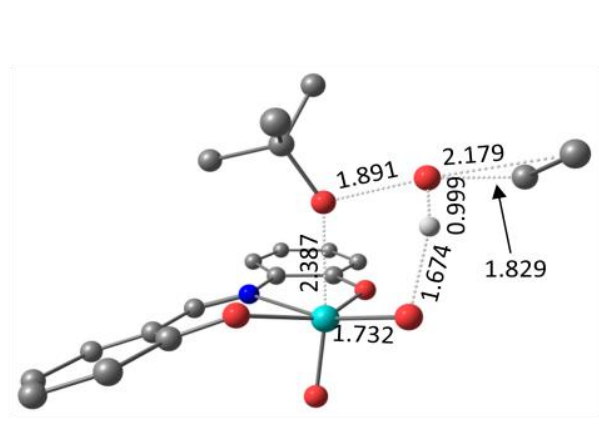

$\mathrm{L}^{1}$

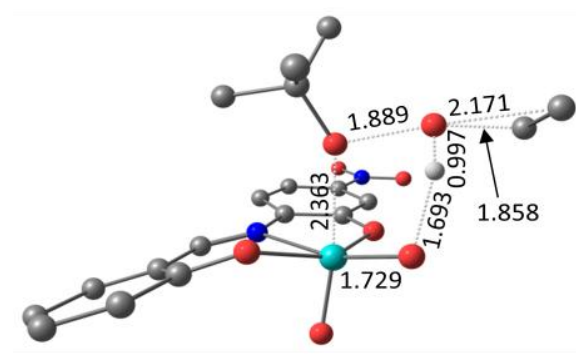

$L^{2}$

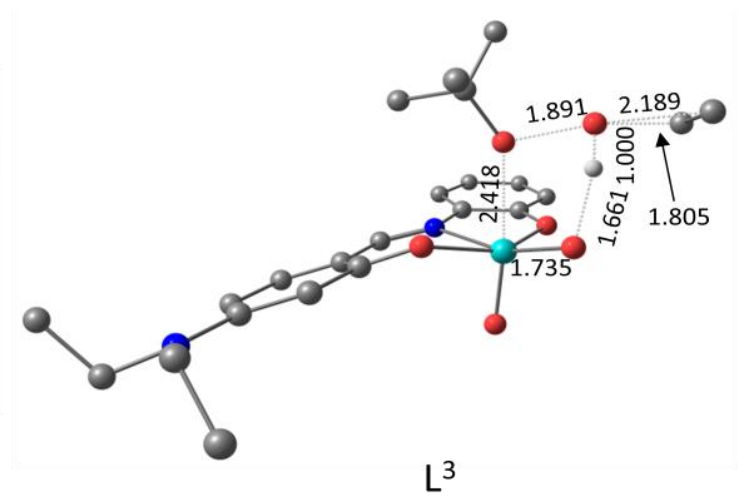

$\mathrm{L}^{3}$

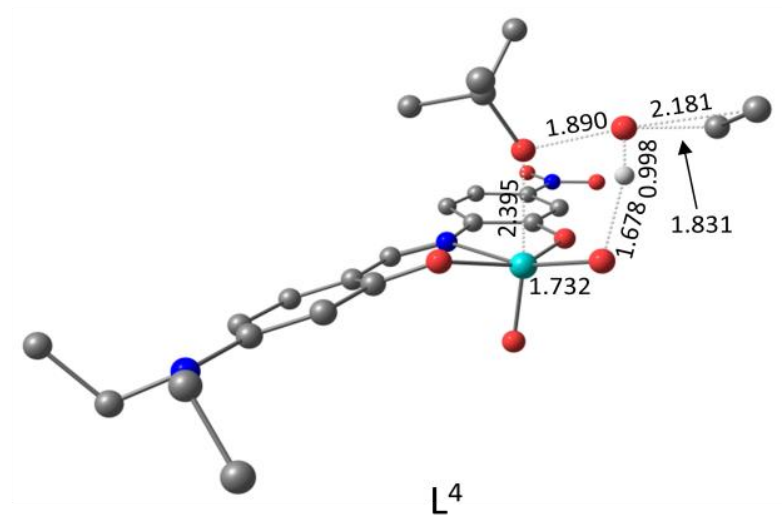

Figure 7. Views and selected distances of the optimized transition states for the ratedetermining $\mathrm{O}$ atom transfer step with the four different catalysts. All $\mathrm{H}$ atoms except the $\mathrm{H}$ atom involved in the proton transfer process have been removed for the sake of clarity.

The most important parameter is the energy span of the catalytic cycle [26]. On the enthalpy scale, it goes in the order $\mathrm{L}^{3}(23.8 \mathrm{kcal} / \mathrm{mol})>\mathrm{L}^{1}(22.5 \mathrm{kcal} / \mathrm{mol}) \sim \mathrm{L}^{4}(22.3$ $\mathrm{kcal} / \mathrm{mol})>\mathrm{L}^{2}(21.0 \mathrm{kcal} / \mathrm{mol})$. The same trend is calculated on the Gibbs energy scale $\left(\mathrm{L}^{3}\right.$, $\left.37.0 ; \mathrm{L}^{1}, 35.5 ; \mathrm{L}^{4}, 35.5 ; \mathrm{L}^{2}, 34.2 \mathrm{kcal} / \mathrm{mol}\right)$, since the entropic contribution is essentially the 
same for all systems. This trend is in agreement with the experimentally observed faster epoxidation in the presence of the $\mathrm{L}^{2}$ complex, with the slower epoxidation in the presence of the $\mathrm{L}^{3}$ complex, and with an intermediate and nearly equivalent activity in the presence of the $\mathrm{L}^{1}$ and $\mathrm{L}^{4}$ complexes.

\section{Conclusions}

We have explored in this study the electronic effect of substituents on tridentate ONO-type Schiff base ligands (L), which are based on the salicylidene-2-aminophenolato structure, on the solvent-free molybdenum catalyzed epoxidation of cyclooctene. The presence of an electron-withdrawing nitro group increases the catalytic activity, whereas the electrondonating diethylamino group decreases it, although the measured effects are rather small. A DFT computational analysis, building on the recently established catalytic cycle that involves the $\left[\mathrm{MoO}_{2}(\mathrm{ONO})\right] \cdots$ TBHP adduct as resting state and a Bartlett-style oxygen atom transfer to external olefin as the rate-determining transition state of the cycle, suggests that the substituent electronic effects affect the cycle energy span mostly through their effect on the transition state energy, whereas their effect on the resting state energy is relatively unimportant, given the weakness of the Mo-THBP interaction and the compensation of the opposite effects on the $\mathrm{Mo} \cdots \mathrm{O}_{\beta}$ and $\mathrm{Mo}=\mathrm{O} \cdots \mathrm{H}$ interactions.

\section{Acknowledgements}

The present work has been carried out within the framework of the French-Mexican International Laboratory (LIA) LCMMC-CONACYT. We acknowledge the Centre National de la Recherche Scientifique (CNRS) and the Institut Universitaire de France (IUF) for financial support. We thank the Universidad Nacional Autónoma de México, the Université Paul Sabatier and its Institut Universitaire Technologique for the facilities, the China Scholarshop Council for the fellowship of W.W. (No.201208370239), and CONACyT for the grant (No. 318435) to T. G.

\section{References}


[1] E. N. Jacobsen, A. Pfaltz, H. Yamamoto, Comprehensive Asymmetric Catalysis, Springer, Berlin, (1999).

[2] (a) R. N. McDonald, R. N. Steppel, J. E. Dorsey, Org. Synth. 50 (1970) 15. (b) E. Rose, B. Andrioletti, S. Zrig, M. Quelquejeu-Etheve, Chem. Soc. Rev., 34 (2005) 573. (c) M. Bagherzadeh, L. Tahsini, R. Latifi, L. K. Woo, Inorg. Chim. Acta, 362 (2009) 3698.

[3] (a) P. Tundo and al, P. Appl. Chem. 72 (2000) 1207. (b) P.T. Anastas, J.C. Warner,Green Chemistry: Theory and Practice, Oxford University Press: New York, (1998) 30 .

[4] R.A. Sheldon, I. Arends, U. Hanefeld, Green Chemistry and Catalysis, Wiley VCH, 2007

[5] R. Landau, G. A. Sullivan, D. Brown, Chemtech, 9 (1979) 602.

[6 ] J. Kollar (Halcon International), US 3350422, 1967;J. Kollar (Halcon International), US 3351635, 1967;J. Kollar (Halcon International), US 3507809, 1970;J. Kollar (Halcon International), US 3625981, 1971.

[7] (a) J. Pisk, D. Agustin, V. Vrdoljak, R. Poli, Adv Synth Catal, 353 (2011) 2910. (b) J. Pisk, B. Prugovečki, D. Matković-Čalogović, R. Poli, D. Agustin, V. Vrdoljak, Polyhedron, 33 (2012) 441. (c) J. Morlot, N. Uyttebroeck, D. Agustin, R. Poli, ChemCatChem, 5 (2013) 601. (d) M. Loudidi, D. Agustin, A. Benharref, R. Poli, C.R. Chimie, 17 (2014) 549. (e) J. Pisk, B. Prugovečki, D. Matković-Čalogović, T. Jednačak, P. Novak, D. Agustin, V. Vrdoljak, RSC Adv., 4 (2014) 39000. (f) W. Wang, T. Vanderbeeken, D. Agustin, R. Poli, Cat. Commun. (2014), in press, doi: 10.1016/j.catcom.2014.08.018. (g) V. Vrdoljak, J. Pisk, D. Agustin, P. Novak, J. Parlov Vuković, D. Matković-Čalogović. New J. Chem., 38 (2014) 6176.

[8] C. Cordelle, D. Agustin, J.-C. Daran, R. Poli, Inorg Chim Acta, 364 (2010) 144.

[9] B. Guérin, D. Mesquita Fernandes, J.-C. Daran, D. Agustin, R. Poli: New. J. Chem. 37 (2013) 3466.

[10] P. D. Bartlett, Rec. Chem. Prog. 11 (1950) 47.

[11] (a) J. Topich, Inorg. Chem. 20 (1981) 3704. (b) J. Topich, Inorg. Chim. Acta, 46 (1980) L37.

[12] G. J. J. Chen, J. W. McDonald, W. E. Newton, Inorg. Chem. 15 (1976) 2612.

[13] B. O. Öztürk, E. Bucak, S. Karabulut, J. Mol. Cat. A: Chem. 376 (2013) 53.

[14] M. Rodríguez, M. E. Ochoa, R. Santillán, N. Farfán, V. Barba, J. Organomet. Chem. 690 (2008) 2975. 
[15] K. A. Neeraj; V. Kumar, R. Prajapati, S.K. Asthana, K. K. Upadhyay, J. Zhao, Dalton Trans. (2014) 5831.

[16] B. Muñoz, R. Santillán, M. Rodríguez, J. M. Méndez, M. Romero, N. Farfán, P. Lacroix, K. Nakatani, G. Ramos-Ortíz, J. L. Maldonado, J. Organomet. Chem. 693 (2008) 1321.

[17] M. J. Frisch, G.W. Trucks, H.B. Schlegel, G.E. Scuseria, M.A. Robb, J.R. Cheeseman, G. Scalmani, V. Barone, B. Mennucci, G. A. Petersson, H. Nakatsuji, M. Caricato, X. Li, H. P. Hratchian, A. F. Izmaylov, J. Bloino, G. Zheng, J.L. Sonnenberg, M. Hada, M. Ehara, K. Toyota, R. Fukuda, J. Hasegawa, M. Ishida, T. Nakajima, Y. Honda, O. Kitao, H. Nakai, T. Vreven, J. A. Montgomery, J. E. Peralta, F. Ogliaro, M. Bearpark, J. J. Heyd, E. Brothers, K. N. Kudin, V. N. Staroverov, R. Kobayashi, J. Normand, K. Raghavachari, A. Rendell, J. C. Burant, S. S. Iyengar, J. Tomasi, M. Cossi, N. Rega, N. J. Millam, M. Klene, J. E. Knox, J. B. Cross, V. Bakken, C. Adamo, J. Jaramillo, R. Gomperts, R. E. Stratmann, O. Yazyev, A. J. Austin, R. Cammi, C. Pomelli, J. W. Ochterski, R. L. Martin, K. Morokuma, V. G. Zakrzewski, G. A. Voth, P. Salvador, J. J. Dannenberg, S. Dapprich, A. D. Daniels, Ö. Farkas, J. B. Foresman, J. V. Ortiz, J. Cioslowski, D. J. Fox, Gaussian 09, Revision D.01, Gaussian, Inc., Wallingford CT, 2009.

[18] D. Agustin, C. Bibal, B. Neveux, J.-C. Daran, R. Poli, Z. Anorg. Allg. Chem. 635 (2009) 2120.

[19] G. M. Sheldrick, Acta Cryst. A 64 (2008)112.

[20] A. Altomare, M. C. Burla, M. Camalli, G. L. Cascarano, C. Giacovazzo, A. Guagliardi, A. G. G. Moliterni, G. Polidori, R. Spagna, J. Appl. Cryst. 32 (1999)115.

[21] G. M. Sheldrick, SHELXL-2013 (2013) University of Göttingen.

[22] (a) L. J. Farrugia, J. Appl. Cryst. 30 (1997) 565. (b) M. N. Burnett, C. K. Johnson, ORTEPIII. Report ORNL-6895, Oak Ridge National Laboratory, Tennessee, USA, (1996)

[23] O. A. Rajan, A. Chakravorty, Inorg. Chem. 20 (1981) 660.

[24] M. Cindric, N. Strukan, V. Vrdoljak, B. Kamenar, Boris, Z. Anorg. Allg. Chem. 630 (2004) 585.

[25] (a) M. Bagherzadeh, S. G. Esfahani, Scientia Iranica C, 17 (2010) 131. (b) C. Bibal, J.C. Daran, S. Deroover, R. Poli, Polyhedron, 29 (2010) 639. (c) J. M. Sobczak, J. J. Ziolkowski, Appl. Catal., A: Gen. 248 (2003) 261. (d) D. D. Agarwal, S. Shrivastava, 
Polyhedron 7 (1988) 2569. (e) D. D. Agarwal, J. Mol. Catal. 44 (1988) 65. (f) Z. Dawoodi, R. L. Kelly, Polyhedron 5 (1986) 271. (g) A. Rezaeifard, M. Jafarpour, H. Raissi, M. Alipour, H. Stoeckli-Evans, Z. Anorg. Allg. Chem. 638 (2012) 1023. (h) A. Rezaeifard, I. Sheikhshoaie, N. Monadi, M. Alipour, Polyhedron 29 (2010) 2703. (i) A. Rezaeifard, I. Sheikhshoaie, N. Monadi, H. Stoeckli-Evans, Eur. J. Inorg. Chem. (2010) 799. (j) Y. Sui, X. Zeng, X. Fang, X. Fu, Y. Xiao, L. Chen, M. Li, S. Cheng, J. Mol. Catal. A: Chem., 270 (2007) 61. (k) X. Zhou, J. Zhao, A. M. Santos, F. E. Kuehn, Z. Naturforsch., B, 59 (2004) 1223. (l) J. Zhao, X. Zhou, A. M. Santos, E. Herdtweck, C. C. Romao, F. E. Kuehn, Dalton Trans. (2003) 3736. (m) L. Casella, M. Gullotti, A. Pintar, S. Colonna, A. Manfredi, Inorg. Chim. Acta 144 (1988) 89.

[26] S. Kozuch, S. Shaik, Acc. Chem. Res., 44 (2011) 101. 